\title{
PERBANDINGAN DOSIS INDUKSI DAN PEMELIHARAAN PROPOFOL PADA OPERASI ONKOLOGI MAYOR YANG MENDAPATKAN
}

\section{COMPARISON OF INDUCTION AND MAINTENANCE DOSE OF PROPOFOL IN ONCOLOGY MAJOR SURGERY PATIENTS WITH AND WITHOUT}

\author{
Ida Bagus Okta, I Made Subagiartha*, Made Wiryana* \\ *Bagian / SMF Ilmu Anestesi dan Terapi Intensif Fakultas Kedokteran Universitas Udayana / Rumah \\ Sakit Umum Pusat Sanglah Denpasar \\ ${ }^{\bowtie}$ Correspondence/ Korespondensi : Ida Bagus Okta
}

\section{ABSTRACT}

Background : General anesthesia the most technique ever done compare to other technique of anesthesia. Total Intravenous Anesthesia using propofol are developed extensively, because of less PONV incidence, cost of anesthesia, and recovery time. Technique, tools and drugs are studied to decrease needs of propofol intraoperative because of life-threatening side effect of propofol, as we know PRIS (propofol related infusion syndrome), could cause fatal morbidity and mortality.

Objective : To compare induction and maintenance dose of propofol needs intraoperative between gabapentin group and control group, furthermore to generalized use of gabapentin as acutely use in perioperative management.

Methods : This study is using double blind clinical trial, to controled reseacher expectation and subject manipulation to the result of study. Study divided two group, gabapentin group and control group. 32 sample each group has done their major oncology surgery using same technique total intravenous propofol with TCI.

Result : Dose of induction in gabapentin group have median $1,15 \mathrm{mg} / \mathrm{kgbw}$ compare to control group have median $1,48 \mathrm{mg} / \mathrm{kgbw}(\mathrm{p}<0,001)$. Maintenance dose to group gabapentin have mean 93,27 mcg/kgbw/minute compare to group control have mean $123,80 \mathrm{mcg} / \mathrm{kgbw} / \mathrm{minute}(\mathrm{p}<0,001)$.

Conclusion : Oral premedication gabapentin $600 \mathrm{mg}$ effective to decrease induction and maintenance doses of propofol use in technique total intravenous anesthesia to maintain surgery. Furthermore gabapentin premedication could generalized use as agent to decrease needs of propofol intraoperative.

Keyword : gabapentin, propofol, total intravenous anesthesia

\begin{abstract}
ABSTRAK
Latar Belakang : Anestesi umum merupakan teknik anestesi yang paling sering dikerjakan dibandingkan dengan teknik anestesi lain. Total Intravena Anestesi menggunakan propofol telah dikembangkan secara luas, karena menurunnya angka insiden PONV, biaya anestesi yang lebih murah, dan waktu pulih yang cepat. Berbagai
\end{abstract}


teknik, alat dan obat-obatan diteliti untuk mengurangi dosis propofol yang diperlukan durasi operasi karena efek samping propofol yang berbahaya, yang dikenal PRIS (Propofol Related Infusion Syndrome), yang dapat menyebabkan morbiditas dan mortalitas yang tinggi.

Tujuan : Untuk membandingkan dosis induksi dan pemeliharaan propofol yang diperlukan intraoperatif antara kelompok gabapentin dan kelompok kontrol. Selanjutnya hasil penelitian dapat digunakan secara umum dalam penggunaan gabapentin sebagai obat akut pada periode perioperatif.

Metode : Penelitian ini adalah double blind clinical trial. Teknik penelitian ini dapat mengkontrol ekspektasi dan manipulasi subjek penelitian terhadap prosedur penelitian sehingga dapat menghasilkan hasil yang valid dan terpercaya. Penelitian dibagi menjadi dua kelompok, kelompok gabapentin dan kelompok kontrol. 32 sampel tiap kelompok telah menjalani operasi onkologi mayor dengan teknik anestesi yang sama total intravena propofol dengan TCI.

Hasil : Dosis induksi kelompok gabapentin memiliki $1,15 \mathrm{mg} / \mathrm{kgbb}$ dibandingkan dengan kelompok kontrol yang memiliki median $1,48 \mathrm{mg} / \mathrm{kgbb}(\mathrm{p}<0,001)$. Dosis pemeliharaan kelompok gabapentin memiliki median 93,27 mcg/kgbb/menit dibandingkan kelompok kontrol yang memiliki median 123,80 mcg/kgbb/menit ( $\mathrm{p}<$ 0,001).

\section{PENDAHULUAN}

Anestesi umum merupakan teknik anestesi yang paling sering digunakan dibandingkan dengan teknik anestesi lain. 70-80 persen kasus pembedahan memerlukan tindakan anestesi umum. Anestesi intravena total merupakan salah satu bagian dari teknik anestesi umum. ${ }^{1,2}$ Pada penelitian tentang cost anestesi didapatkan anestesi intravena total lebih rendah dibandingkan teknik anestesi umum inhalasi isoflurane dengan kelebihan lain yaitu onset yang cepat, angka insiden PONV yang lebih rendah, dan waktu pemulihan yang lebih cepat. 3,4

Propofol merupakan agen anestesi intravena yang paling sering digunakan dalam praktek sehari-hari. Onset kerja cepat, antimuntah, waktu pulih singkat, anti-inflamasi, menurunkan CMRO2 otak, merupakan beberapa kelebihan dari efek propofol yang sudah terbukti dalam penelitian sebelumnya., ${ }^{5,6}$ Nyeri pada saat penyuntikan, hipotensi, dan PRIS merupakan efek samping yang paling dihindari pada saat seorang ahli anestesi menggunakan propofol. ${ }^{5}$ PRIS (Propofol Related Infusion Syndrom) adalah efek samping propofol yang paling berbahaya dengan tingkat mortalitas dan morbiditas yang tinggi. Menurunkan kebutuhan dosis propofol durasi operasi dapat menurunkan resiko terjadinya PRIS. Teknik pemberian 
dengan alat dan tambahan adjuvan obat sudah diteliti dalam usaha menurunkan kebutuhan propofol durasi tindakan diagnostik maupun operasi. ${ }^{1,2,5,7}$ Penggunaan TCI dan BIS indeks memungkinkan pemberian propofol yang lebih efisien. ${ }^{1,2}$ Penggunaan TCI dan BIS juga memungkinkan dilakukannya studi obat adjuvan yang digunakan untuk mengurangi dosis propofol. $^{1,2}$

Pada penelitian sebelumnya gabapentin dapat menurunkan tingkat kecemasan preoperasi, serta menurunkan dosis induksi dan pemeliharaan propofol yang diperlukan durasi operasi mastektomi. Pada penelitian ini ide yang digunakan sama, namun dengan mengubah metode teknis yang digunakan pada penelitian sebelumnya yang menggunakan syringe pump dan N2O menjadi murni menggunakan propofol dengan mesin TCI dan monitor BIS indeks. ${ }^{7}$

\section{METODE}

Penelitian ini menggunakan teknik double blind clinical trial, untuk meminimalisir ekspektasi dan manipulasi subjek sehingga menghasilkan hasil yang sangat dipercaya. Penelitian ini dibagi menjadi 2 kelompok, kelompok 1 adalah kelompok gabapentin, kelompok 2 adalah kelompok kontrol. Setelah dilakukan perhitungan jumlah dengan formula rumus penelitian analitik dengan skala data numerik tidak berpasangan, serta menggunakan standar deviasi gabungan dari penelitian sebelumnya (Neerja Bharti 2013), didapatkan 29 sampel yang diperlukan tiap kelompok. Dengan menghitung 10 persen angka kemungkinan sampel mengalami drop out, jumlah sampel yang diperlukan tiap kelompok adalah 32 sampel.

Sampel penelitian ini dilakukan di ruang operasi bedah sentral RSUP Sanglah Denpasar antara bulan September hingga Oktober 2016. Dengan menetapkan kriteria inklusi adalah pasien yang akan dilakukan operasi bedah mayor onkologi dengan anestesi umum dengan usia antara 1664 tahun. Sedangkan kriteria eksklusi sampel adalah pasien yang menolak ikut serta / menandatangani informed consent, status fisik ASA III, IV dan V, BMI kurang dari $18,5 \mathrm{~kg} / \mathrm{m} 2$ atau lebih dari $30 \mathrm{~kg} / \mathrm{m} 2$, alergi dengan obatobatan yang akan diberikan selama penelitian ini, serta pasien-pasien yang memiliki riwayat kelainan kardiovaskular, psikiatri, defisit neurologis, dan serebrovaskular. Sehingga didapatkan sampel eligibel yang ditargetkan sebanyak 32 orang tiap kelompok.

Semua sampel yang didapatkan diberikan premedikasi oral dalam bentuk kapsul dan diberikan penomoran oleh pihak ketiga. Kemudian pada semua sampel mendapatkan perlakuan yang sama yaitu anestesi total intravena dengan propofol TCI, dosis premedikasi midazolam sesuai berat 
badan, dosis fentanyl sesuai berat badan, NSAID sesuai berat badan. Kemudian dilakukan pencatatan dosis propofol saat induksi dan pemeliharaan, fluktuasi hemodinamik (tekanan darah, Nadi), waktu pulih, dan efek samping yang terjadi. Setelah semua sampel terpenuhi pihak ketiga memberikan data penomoran sampel dan jenis obat premedikasi yang didapatkan dalam kapsul (gabapentin 600 mg atau gula).

Variabel bebas pada penelitian ini adalah pemberian obat premedikasi gabapentin atau plasebo. Variabel tergantung pada penelitian ini adalah jumlah dosis propofol induksi dan pemeliharaan. Sedangkan variabel perancu dibagi menjadi dua yaitu variabel yang dikontrol dengan distribusi frekuensi dan uji statistik adalah jenis kelamin, umur, status Fisik ASA, dan BMI. Sedangkan variabel yang dikontrol dengan design penelitian adalah mode TCI, kedalaman anestesi dengan BIS indeks, ETCO2, Jumlah opioid, jumlah dosis NSAID, midazolam, jenis operasi dan lama operasi. Variabel perancu dikontrol dengan design penelitian dan dengan analisa statistik.

Definisi operasional dosis propofol induksi adalah jumlah dosis propofol yang disuntikan dan direkam dengan mesin TCI mulai dari pasien sadar hingga terhipnotis dengan monitor BIS indeks menunjukan 40-60, dikalikan 10, kemudian dibagi dengan berat badan pasien (mg/kgBB). Dosis propofol pemeliharaan adalah jumlah volume propofol yang disuntikan dan direkam dari mesin TCI dari mulai insisi pembedahan hingga operasi selesai yang ditandai dengan jahitan luka terakhir, jumlah volume yang disuntikan dikali 10.000, kemudian dibagi berat badan dalam kilogram dan durasi waktu operasi dalam menit, satuan dosis pemeliharaan dengan mikrogram perkilogram berat badan permenit (mcg/kgbb/menit).

\section{HASIL}

64 sampel telah berhasil menjalani prosedur penelitian, dan tidak ada sampel yang mengalami drop out.

Berdasarkan analisa statistik dengan Chi-Square test dan Mann-Whitney test yang ditampilkan pada tabel 1.1 didapatkan pada kedua kelompok tidak didapatkan perbedaan karakteristik subjek yang bermakna $(p>0,05)$. Sehingga hasil penelitian ini tidak lagi dipengaruhi oleh perbedaan karakteristik pada kedua kelompok.

Hasil analisa statistik data rerata dosis induksi dan pemeliharaan yang ditampilkan pada tabel 1.2 didapatkan dosis yang dibutuhkan pada kelompok gabapentin lebih rendah daripada kelompok kontrol dan secara statistik berbeda bermakna $\mathrm{p}<0,001$.

Hasil pencatatan dan uji statistik waktu pulih sadar pada kedua kelompok didapatkan pada kelompok gabapentin median 6 menit, sedangkan pada 
kelompok kontrol median 6 menit. Setelah dilakukan uji statistik dengan Mann Whitney test nilai $\mathrm{p}=0,47$, secara statistik tidak berbeda bermakna.

\section{PEMBAHASAN}

Pada awal ditemukannya gabapentin merupakan obat yang digunakan sebagai pengobatan antikejang epilepsi. $^{8} \quad$ Seiring berkembangnya waktu beberapa studi mengatakan obat ini dapat digunakan sebagai obat antinyeri kronis / nyeri kanker. ${ }^{8}$ Berdasarkan studi saat ini penggunaan gabapentin lebih mengarah kepada penggunaan akut yang digunakan sebagai adjuvan anti-nyeri perioperatif, anti-cemas perioperatif, pencegahan nyeri kronis perioperatif, serta yang terbaru dikerjakan studi mengenai pengaruh gabapentin terhadap dosis sedasi-hipnotik yang digunakan perioperatif. $^{7,9}$

Mekanisme kerja gabapentin adalah menghambat masuknya kalsium dan pengurangan pelepasan neurotransmiter excitatory melalui $N$ methyl $D$ aspartate (NMDA) dan mengurangi aktivasi dari reseptor 2-amino-3- (5methyl-3-oxo-1,2-oxazol-4-yl)

propanoic acid (AMPA). ${ }^{10,11}$ Laporan dari studi di Taiwan gabapentin menurunkan secara bermakna dosis induksi dan pemeliharaan propofol yang dibutuhkan pada operasi mastektomi. ${ }^{7}$ Obat ini dikombinasikan dengan propofol efektif digunakan sebagai agen penanganan kejang refrakter. ${ }^{9}$ Berdasarkan studi tersebut obat ini memiliki efek yang sinergis terhadap propofol.

Penelitian ini merupakan penelitian uji klinis dengan metode double blind, metode ini merupakan metode paling mutakhir dan terpercaya yang digunakan untuk membandingkan perbedaan efek obat dengan kontrolnya. Prosedur penelitian berhasil dijalankan pada 64 eligible sample.

Dalam pengetahuan penulis belum banyak clinical trial yang dilakukan untuk mengevaluasi efek gabapentin terhadap dosis propofol intraoperatif. Namun, penelitian terbaru pada efek gabapentin terhadap nyeri pasien pasca kraniotomi melaporkan juga adanya penurunan konsumsi propofol setelah diberikan gabapentin 1200 mg. ${ }^{12}$ Penurunan konsumsi propofol pada pasien yang mendapatkan gabapentin kemungkinan disebabkan karena efek potensiasi secara langsung terhadap obat-obatan anestesi melalui efek antagonis NMDA dari gabapentin. Mekanisme lain yang dapat berperan dalam penurunan konsumsi propofol adalah menurunnya pelepasan katekolamin atau respon stress terhadap pembedahan. $^{13}$

Bioavailabilitas gabapentin pada dosis $300 \mathrm{mg}$ adalah $\approx 60 \%$, sedangkan pada dosis $600 \mathrm{mg}$ adalah $\approx 40 \%$, dan menurun dan menetap $\approx 35 \%$, pada dosis $1600 \mathrm{mg}$ yang dibagi dalam tiga kali pemberian. Kadar puncak di dalam plasma (Cmax) gabapentin adalah 2,7 2,99 mg/L dicapai dalam $2-3,2$ jam 
setelah pemberian dosis tunggal 300 mg. Sebagai akibat dari absorbsi gabapentin yang jenuh tergantung dosis, Cmax meningkat kurang dari tiga kali lipat bila dosisnya dinaikkan dari $300 \mathrm{mg}$ mejadi $900 \mathrm{mg}$. Dari penelitian sebelumnya juga ditemukan gabapentin 600 mg tidak menimbulkan efek samping yang signifikan kecuali dizzines yang ringan pada beberapa pasien. Tidak ditemukan efek samping seperti sakit kepala, tremor, ataksia, nistagmus, sedasi berlebihan, dan depresi pernafasan. ${ }^{14}$ Berdasarkan literatur tersebut dipilih dosis oral gabapentin $600 \mathrm{mg}$ diberikan 2 jam sebelum tindakan operasi.

Dari data pencatatan dan uji statistik karakteristik jenis kelamin, umur, BMI, ASA, sampel tidak berbeda bermakna $(p>0,05)$, sehingga hasil penelitian ini tidak lagi dipengaruhi oleh perbedaan karakteristik pada kedua kelompok penelitian. Variabel mode TCI, kedalaman anestesi dengan monitor BIS indeks, ETCO2, Jumlah opioid perkilogram berat badan persatuan waktu, jumlah dosis ketorolac perkilogram berat badan, midazolam perkilogram berat badan, jenis operasi dan lama operasi juga dilakukan pengontrolan ketat secara prosedural desain penelitian sehingga tidak ada perbedaan yang bermakna pada kedua kelompok yang dapat mempengaruhi hasil penelitian dan tidak diperlukan pembuktian secara statistik.

Hasil pencatatan perbandingan dosis induksi propofol yang digunakan pada kelompok gabapentin lebih rendah (median 1,15 mg/kgbb) dibandingkan kelompok kontrol (median 1,48 mg/ kgbb), perbedaan dosis induksi diperkuat dengan uji statistik MannWhitney test dengan $p<0,001$. Hasil tersebut memperkuat hasil penelitian Neerja bharti 2013 di Taiwan yang menyatakan dosis induksi propofol lebih rendah pada kelompok gabapentin (kempompok gabapentin median 1,44 $\mathrm{mg} / \mathrm{kgbb}$, sedangkan kelompok kontrol 1,66 mg/kgbb). Perbedaan hasil pada penelitian ini dibandingkan penelitian di taiwan kemungkinan disebabkan pada penelitian ini menggunakan teknik TIVA menggunakan alat TCI, sedangkan pada penelitian Neerja bharti menggunakan alat syringe pump.

Hasil perbandingan dosis pemeliharaan propofol yang digunakan pada kelompok gabapentin lebih rendah (median 93,27 $\pm 6,1 \mathrm{mcg} / \mathrm{Kgbb} /$ menit) dibandingkan kelompok kontrol (median 123,81 $\pm 18,1 \mathrm{mcg} / \mathrm{kgbb} /$ menit), perbedaan dosis pemeliharaan propofol diperkuat dengan uji statistik Mann-Whitney test $p<0,001$. Selaras dengan penelitian ini hasil penelitian Neerja bharti dimana dosis pemeliharaan kelompok gabapentin median 73,50 $\mathrm{mcg} / \mathrm{kgbb} /$ menit lebih rendah dibandingkan kelompok kontrol 93,85 $\mathrm{mcg} / \mathrm{kgbb} / \mathrm{menit}$ dengan $\mathrm{p}=$ 0,009. Perbedaan hasil dosis pemeliharaan propofol pada penelitian ini dibandingkan dengan penelitian Neerja bharti kemungkinan disebabkan 
pada penelitian Neerja bharti menggunakan N2O 60\% sebagai agen kombinasi pemeliharaan dengan propofol, sedangkan pada penelitian ini hanya menggunakan agen pemeliharaan propofol TCI.

Sebagai data penunjang tambahan pada penelitian ini juga dicatat konsentrasi TCI minimum dan maksimum untuk pemeliharaan anestesi durasi operasi dengan panduan target tercapainya BIS Indeks 50-60 pada kedua kelompok. Didapatkan konsentrasi target TCI minimum pada kelompok gabapentin median 1,6 $\mathrm{mcg} / \mathrm{ml}$ sedangkan pada kelompok kontrol median 2,2 mcg/ml, konsentrasi target TCI maksimum pada kelompok gabapentin median 2,2 mcg/ ml sedangkan pada kelompok kontrol $2,5 \mathrm{mcg} / \mathrm{ml}$. Perbedaan hasil pada kelompok terbukti dengan uji statistik non parametrik Mann Whitney tes (data tidak berdistribusi normal) $p<0,001$.

Efek sinergis gabapentin-propofol dalam proses pemeliharaan sedasihipnotika menimbulkan perkiraan dapat memperpanjang waktu pulih, sehingga dilakukan pencatatan waktu pulih pada kedua kelompok untuk dibandingkan. Dari hasil didapatkan tidak ada perbedaan bermakna dari waktu pulih pada kelompok gabapentin (median 6 menit) dibandingkan kelompok kontrol (median 6 menit), hasil ini diperkuat dengan uji statistik dengan Mann Whitney tes $p=0,47$.

Dilakukan pencatatan pemantauan fluktuasi hemodinamik tekanan arteri retata dan laju nadi pada empat kondisi (basal, induksi, laringoskopi-intubasi, insisi pembedahan). Dari grafik 1.1 dan 1.2 tampak perbedaan nominal angka fluktuasi tekanan arteri rerata dan laju nadi, namun dari hasil pencatatan perbedaan nominal angka tersebut tidak bermakna secara klinis.

\section{SIMPULAN}

Gabapentin menurunkan dosis induksi dan pemeliharaan propofol secara efektif. Gabapentin juga tidak memperpanjang waktu pulih dibandingkan dengan kelompok kontrol. Tidak ada efek samping atau komplikasi yang berarti pada kedua kelompok penelitian. Penggunaan gabapentin oral sebagai premedikasi dapat digeneralisir pada operasi lain. 
Tabel 1.1 Karakteristik Subyek Berdasarkan Kelompok Perlakuan

\begin{tabular}{lccc}
\hline Karakteristik & \multicolumn{2}{c}{ Kelompok Perlakuan } & \multirow{2}{*}{ Nilai $\boldsymbol{p}$} \\
\cline { 2 - 3 } & $\mathbf{G}(\mathbf{n}=\mathbf{3 2})$ & $\mathbf{K}(\mathbf{n}=\mathbf{3 2})$ & \\
\hline $\begin{array}{l}\text { Jenis kelamin : } \\
\text { Laki-laki f }(\%)\end{array}$ & $7(69,2)$ & $3(92,5)$ & $0,168^{\mathrm{a}}$ \\
$\quad \begin{array}{l}\text { Perempuan f }(\%) \\
\text { Umur (tahun) }\end{array}$ & $25(30,8)$ & $28(7,7)$ & \\
(Median) & $49(13)$ & $45,5(18)$ & $0,979^{\mathrm{b}}$ \\
BMI (Median) & 23,55 & & \\
& & & $0,234^{\mathrm{b}}$ \\
Status fisik ASA : & & & \\
ASA 1 f $(\%)$ & $10(31,2)$ & $15(46,9)$ & $0,200^{\mathrm{a}}$ \\
ASA 2 f $(\%)$ & $22(68,8)$ & $17(53,1)$ & \\
\hline
\end{tabular}

Keterangan :

$\mathrm{G} \quad=$ Kelompok Gabapentin

$\mathrm{K}=$ Kelompok Kontrol

$\mathrm{f}(\%)=$ Frekuensi (Persentase $)$

$\mathrm{SD}=$ Standar Deviasi

a $\quad=$ Chi-Square test

Tabel 1.2 Hasil Analisis Perbedaan Rerata Dosis Induksi (satuan miligram/kilogram berat badan) dan Pemeliharaan Propofol

Berdasarkan Kelompok Perlakuan (satuan mikrogram/kilogram berat

\begin{tabular}{lccc|c}
\hline \multicolumn{1}{c}{ Variabel } & \multicolumn{2}{c}{ Perlakuan } & \multirow{2}{*}{$\begin{array}{c}\text { Beda } \\
\text { rerata }\end{array}$} & Nilai $\boldsymbol{p}$ \\
\cline { 2 - 3 } & $\mathbf{G ~ ( n = 1 3 )}$ & $\mathbf{K}(\mathbf{n}=\mathbf{1 3})$ & 0,33 & $<0,001^{\mathrm{a}}$ \\
\hline Induksi & $1,15(\mathrm{IR} \mathrm{0,2)}$ & $1,48(\mathrm{IR} \mathrm{0,2)}$ & 0 & \\
\hline Pemeliharaan & $\mathrm{mg} / \mathrm{KgBB}$ & $\mathrm{Mg} / \mathrm{KgBB}$ & & $<0,001^{\mathrm{a}}$ \\
(rerata $\pm \mathrm{SD})$ & $\mathrm{Mcg} / \mathrm{Kgbb} / \mathrm{menit}$ & $\begin{array}{c}123,81 \pm 18,1 \\
\mathrm{mcg} / \mathrm{kgbb} / \mathrm{menit}\end{array}$ & 30,54 & \\
\hline Waktu Pulih & 6 (menit) & 6 (menit) & 0 & 0,47 \\
\hline
\end{tabular}

Keterangan :

$\mathrm{G} \quad=$ Kelompok Gabapentin

$\mathrm{K} \quad=$ Kelompok Kontrol

$\mathrm{SD}=$ Standar Deviasi 


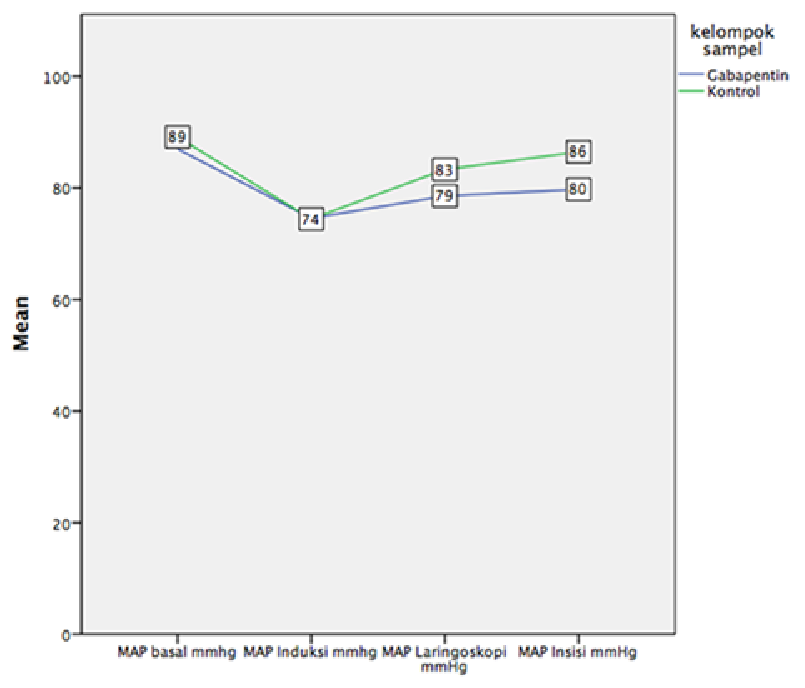

Gambar 1.1 Grafik Fluktuasi Hemodinamik Tekanan Arteri Rerata (MAP) saat basal, induksi, laringoskopi-intubasi dan Insisi Pembedahan

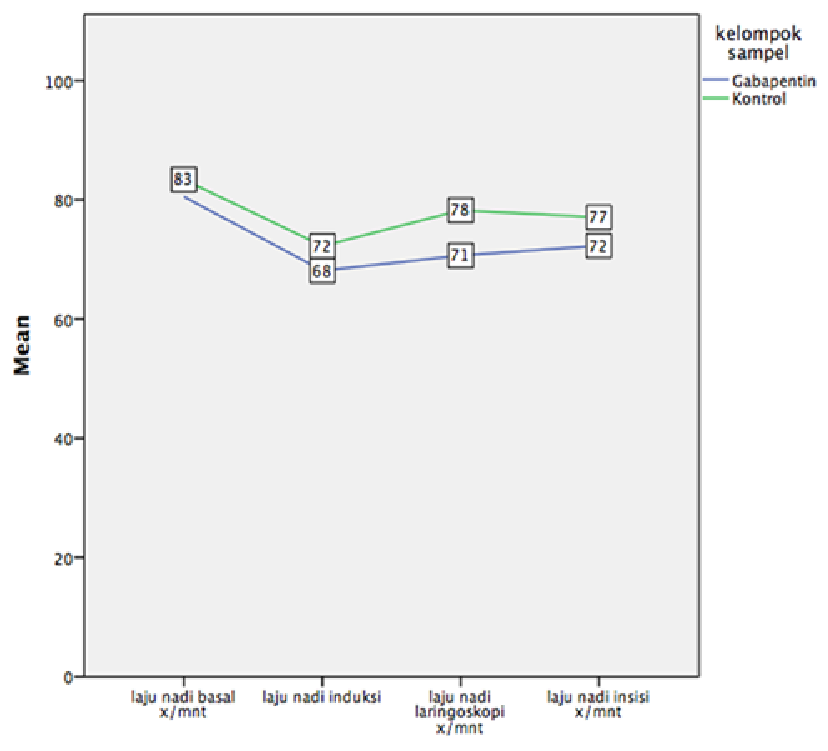

Gambar 1.2 Grafik Fluktuasi Hemodinamik Laju Nadi Saat Basal, Induksi, Laringoskopi-Intubasi dan Insisi Pembedahan. 


\section{DAFTAR PUSTAKA}

1. Absalom, A.R., Struys, M. Overview of Target Controlled Infusions and Total Intravenous Anaesthesia. Edisi ke 2. 2007. English: Academia Press.

2. Absalom, A. R., Sutcliffe N., Kenny, G. N. Closed-loop control of anesthesia using bispektral index: performance assessment in patients undergoing major orthopedic surgery under combined general and regional anesthesia. Anesthesiology. 2002.96:67-73.

3. Adi, Pramana, Wiryana. "Analisis minimalisasi biaya anestesi umum propofol target controlled infusion (TCI) dan anestesi inhalasi pada pasien operasi bedah mayor onkologi di RSUP Sanglah". Bagian Anestesiologi dan Terapi Intensif. [Tesis] Denpasar : Fakultas Kedokteran Universitas Udayana; 2015

4. Iswahyudi, Sinardja, K., Senapathi, T.G.A. "Analisis biaya periode intraoperatif anestesi intravena total propofol target controlled infusion (TCI) dengan anestesi inhalasi sevoflurane pada pasien operasi bedah mayor onkologi di RSUP Sanglah Tahun 2013". Bagian Anestesiologi dan Terapi Intensif. [Tesis] Denpasar : Fakultas Kedokteran Universitas Udayana; 2013

5. Stoelting, R. K., Hiller, S. C. Nonbarbiturate Intravenous Anesthetic Drugs. Dalam : Pharmacology \& Physiology in Anesthetic Practice. Edisi ke 4. Philadelphia: Lippincott William \& Wilkins. 2006;155-63

6. Bertram, G., Katzung. Basic and Clinical Pharmacology. 2004; 9:41314
7. Bharti, Neerja., Bala, Indu., Narayan, Vidhya., Singh, Gurpret. Effect of gabapentin pretreatment on propofol consumption, hemodynamic variables, and postoperative pain relief in breast cancer surgery. Acta Anaesthesiologica Taiwanica. 2013. 10-13.

8. Bertrand, S., dkk. The Anticonvulsant, Antihyperlagesic Agent Gabapentin Is an Agonist at Brain $\gamma$-Aminobutyric Acid Tupe B Receptors Negatively Coupled to Voltage-Dependent Calcium Channels. J Pharmacol Exp Ther. 2001; 298: 15-24.

9. Pandey, C.K., et al. Pre-emptive use of Gabapentin significantly decrease post operative \& rescue analgesic requirement in laparoscopic cholecystectomy. Can J Anaes. 2004; 51(4): 358-362.

10.Patel, M.K., Gonzalez, M.I., Bramwell, S., Pinnock, R.D., Lee, K. Gabapentin inhibits excitatory synaptic transmission in the hyperalgesic spinal cord. $\mathrm{Br} \mathrm{J}$ Pharmacol; 2000; 130:1731-1734.

11.Rose, M.A., Kam, P.C.A. Gabapentin : pharmacology and its use in pain management. Anaesthesia. 2002.57: 451-462.

12.Türe $H$, Sayin $M$, Karlikaya $G$, Bingol CA, Aykac B, Türe U. The analgesic effect of gabapentin as a prophylactic anticonvulsant drug on postcraniotomy pain: a prospective randomized study. Anesth Analg 2009; 109:1625e31.

13.Todd RD, McDavid SM, Brindley RL, Jewell ML, Currie KP. Gabapentin inhibits catecholamine release from adrenal chromaffin cells. Anesthesiology 2012;116: $1013 \mathrm{e} 24$.

14.Kade, Senapathi, T.G.A., Wiryana. 